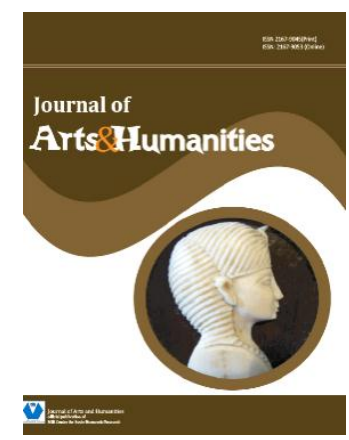

Journal of Arts \& Humanities

Volume 06, Issue 06, 2017, 84-94

Article Received: 04-06-2017

Accepted: 23-06-2017

Available Online: 27-06-2017

ISSN: 2167-9045 (Print), 2167-9053 (Online)

DOI: http://dx.doi.org/10.18533/journal.v6i6.1207

\title{
Defining Art and Its Future
}

\author{
Zachary Isrow ${ }^{1}$
}

\begin{abstract}
Art is a creative phenomenon which changes constantly, not just insofar as it is being created continually, but also in the very meaning of 'art.' Finding a suitable definition of art is no easy task and it has been the subject of much inquiry throughout artistic expression. This paper suggests a crucial distinction between 'art forms' and 'forms of art' is necessary in order to argue that the future of art will bring a new aesthetic in which these properties become recognized as art and as such there will be an aesthetic of everyday life.
\end{abstract}

Keywords: Aesthetics, Art Theory, Philosophy of Art.

This is an open access article under Creative Commons Attribution 4.0 License.

\section{Introduction}

Defining art is a difficult task; it is one which many theorists, artists, and critics have tackled, trying to decide upon the best approach to understanding what we mean by art. It is a question still being asked in contemporary literature (Crowther, 2007; Currie, 2010; Clowney, 2011). Yet it is only through coming to a greater understanding of what art is, that we can then attempt to determine what the future of art will have in store. Should we consider art only that which we find aesthetically pleasurable? In that case, will the future of art bring additional ways of art being made aesthetic? The question of the future of art is directly related to what art is; therefore, it is necessary to first consider a way to understand art, such that we may understand what the future of art may bring.In this paper, I will outline the major positions on the meaning of art in order to draw out a commonality among the many theories. In doing so, I will argue that what we call art is simply a representation of the art forms of which they are a part.

David E. W. Fenner asked "why define 'art'?" instead of just considering it as something subjective and which takes a stance as art merely because one labels it as such (Fenner, 1994). It is something that has been attempted many times by many people. There still is no consensus on what makes art, in fact, art. Nevertheless, there is a great interest in finding a workable definition of art, since most will agree when something is not, and should not be considered, art. This is because art is meant to be appreciated,

${ }^{1} \mathrm{PhD}$ candidate at the Global Center for Advanced Studies and Alma Mater Europaea, GlvaniTrg 2, Maribor, Slovenia, 2000 
even in cases when it is disturbing or controversial. Betty Seabolt suggests that the appreciation of art comes down to "understanding and enjoying art" (Seabolt, 2001). Art is always to be appreciated and the best way for it to be so, is to have a definition of art which enables an appreciation of art.

Still, more recently, Dominic Lopes suggests that no theory of defining art is necessary. He claims we "need a theory of art only if it is settled by a theory of each art form whether a work belongs to the art form and yet it is not settled whether the work is art", in which case no theory is needed since by belonging to an art form, the work has already been considered art (Lopes, 2008). I am mostly in agreement with this sentiment, therefore, not proposing here to attempt a new definition of art itself. Instead, I propose to reconsider how we think of art, in particular 'art forms,' and establish a new distinction between "art forms" and "forms of art." The latter of these corresponds to that which we typically refer to as art, such as painting, singing, etc. The former corresponds to the form out of which these "forms of art" take shape, such as movement, speech, etc. This paper concerns itself more with this rethinking of "art forms" and "forms of art"and what that means for the future of art rather than how this alters the very definition of art. In this way, the paper addresses a concern that is only briefly, if at all, discussed in the typical contemporary literature, most of which focuses on the future of art education (Jagodzinski, 2005; Piene and Russett, 2008; Carrier, 2011) or on particular art styles like feminist art (Wilson, 2008).

\subsection{Methodology}

I approach this topic from a qualitative and historical perspective, analyzing various accounts of art and definitions of art, in an attempt to find similarities among the many approaches. Drawing out the commonalities, that is, by finding what each theory proposes in unison, the distinction between "art forms" and "forms of art" becomes grounded. I believe this commonality is the perceiving of art as representation in some capacity or another. While at times it may appear that this paper is normative, suggesting how art oughtto be considered, it is entirely meant to be descriptive in nature, offering only how art really is or has been defined, and using this historical and qualitative analysis to explore the future of art based on these descriptive claims.

\section{Defining art}

There are several major positions on the best way to define art. In his bookThe Philosophy of Art, Theodore Gracyknames these as functionalist, expressionist, institutional, and cluster definitions, the last of which is simply a mixture of the others (Gracyk, 2012). Functionalist definitions centers on the purpose, or the specific task that art fulfills. That is to say, we can term something art, only if it fulfills or performs a specific function, or possesses certain qualities. We can find potential problems already, as many have, with the functionalist approach to definitions of art. For example, to say art does " $x$," or art possesses " $x$," there immediately exists the possibility of excluding certain works of art which do not fit such narrow categories. On the reverse, if you make the category broad enough, perhaps the definition becomes too inclusive. We therefore find that any definition of art requires more than a focus on the particularities of art.

Expressionist definitions, a version of functionalist definitions, of art attempt to address the problem of finding the "goldilock's zone" between inclusivity and exclusivity by switching the focus to what the work expresses, or even trickier, what it is intended to express. We say then, " $x$ " is art if it expresses a value which art is meant to, or typically does, express. First, intention is difficult, if not impossible, to determine, especially for works whose authors do not leave any mark from which we can determine the artists intention. Further, intention becomes more difficult when the author had no intention whatsoever for the piece to be expressive. Thus, a work of art may not express anything other than the subjective feelings it arises in its audience, which cannot determine its being or not being a work of art. 
Expressionist definitions of art are more useful for determining the quality of art, rather than what can be called art. Consider, for example, the statement " $x$ " is bad art because it does not express " $y$," or it does so inadequately. The failure to express, or express adequately, can be a factor for judging the quality of art, though it rests on a semi-functionalist definition (one must be willing to say that the expression of " $y$ " determines what is art - a rather functionalist way of defining art - and, " $x$ " failing to do so adequately makes it bad art).

Institutional definitions of art stress factors outside of the work itself. A good example of this is the Medicine Cabinets by Damien Hirst. This is considered art, however my medicine cabinet is not; how is it that two similar or identical objects can be considered differently regarding their status as art? This can only be the case if there is an additional "non-manifest" feature of the one. "Perhaps Duchamp's Fountain was a sculpture... because he had an opportunity for exploiting institutional settings - an art exhibition and an avant garde art magazine - that gave it that status" (Gracyk, 2012, p. 111). This is the focus of institutional definitions which assert that this non-manifest feature is the determining factor of art. If one is to claim a piece as a work of art, it is necessary to be acquainted with the social conditions surrounding that piece. For example, George Dickie in Art and the Aesthetic: An Institutional Analysis, argues that naming a work of art 'art' assumes we acknowledge and understand the ideas of public and art-world (Dickie, 1974). ${ }^{2}$

Thus, by understanding, and only through understanding, that Hirst's Medicine Cabinet is at an art gallery, and is presented in a particular way, can we determine that his is a work of art and my cabinet is not. The problem with such definitions of art is that they assert nothing about the actual work, and are only concerned with whether or not it is presented at the right time, in the right place, using the right way, and to the right audience.

Next, Gracyk discusses historical definitions, which suggest that art is only art in reference to particular qualities of past art. Jerrold Levinson defines art saying that "it is a thing (item, object, entity) that has been seriously intended for regard-as-a-work-of-art, i.e., regard in any way preexisting art-works are or were correctly regarded" (Levinson, 1989). To use again, Hirst's cabinet as an example, it is art because he owned the property rights to the cabinet, and submitted it to an art gallery to be recognized for possessing qualities that other works of art, that have been regarded as art, also possessed. This type of definition brings with it many issues. Gracyk mentions two of these issue that are worth further discussion.

First, it seems to be an unnecessary condition that artists own the piece or the product that they create. This does not really add much to art, and much art in the past has been commissioned whereby the artist owns nothing. Second, there is a type of regress problem involved. Where does the first piece of art draw its references from? In other words, the very first art cannot be intended to reflect qualities that have been regarded as art in the past. Gracyk makes notice of this problem and asks "when did the history of art begin?" Following historical definitions, there does not seem to be a solid response to either of these problems.

\section{Aesthetic definitions in history}

Since we find major flaws in each of the major methods of defining art, how then are we left to do so? We must consider the underlying problem with these approaches, before we may appropriately understand art. Some of the first theories regarding art focus on the ability art has to represent the world around us. Most of the ancient philosophers considered the function of art to bemimesis, that art is merely an imitation of appearances.

\footnotetext{
2 "A work of art in the classificatory sense is (1) an artifact (2) a set of the aspects of which has had conferred upon it the status of candidate for appreciation by some person or persons acting on behalf of a certain social institution (the artworld)."
} 
In theRepublic, Plato divides knowledge of things into three classes or categories: forms, objects, and imitations. The paintings we create, the poems we write, and the stories we tell, are all merely limited imitations of actual things, and insofar as they are limited, the arts are not as meaningful, or as important as the actual, true objects and forms. "All such things seem to maim the thought of those who hear them and do not as a remedy have the knowledge of how they really are" (Plato, 1968, 595a). In this way, many arts can be harmful, as they can trick us into identifying something as accurate, despite its being only an imitation; art can rely to us false knowledge of the things depicted.

Aristotle also thought that art was aimed at imitating, or mimesis. His approach was much less negative than was Plato's own account. For Aristotle, the imitation of objects was not providing us with false knowledge but is rather useful. ${ }^{3}$ In fact, we learn through imitation, which eventually leads to habituation, an important aspect in developing virtue. Thus, imitation of nature or of objects can teach us and should be applauded not dispelled. Indeed, it is natural that we take a form of pleasure from the learning we do through mimesis, as Aristotle notes in his Poetics(Aristotle, 1997, 1184b).

Later, in his Critique of Judgement, Kant discusses art in terms of the aesthetic judgements which we make. Specifically, Kantsuggests that 'pure' aesthetic judgements are disinterested, or that they do not arise out of a desire for the object which is the subject of our judgment (Kant, 1987). This pure, or free, beauty, is less common and applies only to art that is abstract, or that does not aim to depict reality, such as instrumental music.

More common are judgments of adherent beauty, as Kant terms it, when considering works of art. Since the natural is the most free, or pure, form of beauty, Kant suggests that the fine arts are to appear as natural as possible. To do so, an artist relies on their intuition, or what Kant calls "genius." "Genius," refers to a specific ability of an artist, to create the beautiful. This is why what an artist creates tends to be aesthetically pleasing, according to Kant (Kant, 1987). This, however, becomes problematic in the post-conceptual era, where many works of art are not aesthetically pleasing, nor are they judged beautiful.

Following from Kant, Hegel critiques previous accounts of what art is, prior to asserting his own perspective. The first thought Hegel questions is the notion that art's purpose is mimesis; or rather to copy or imitate nature. Hegel finds this notion quite absurd and writes that this is "A superfluous labour, seeing that the things which pictures, theatrical representations, etc., imitate and represent animals, natural scenes, incidents of human life - are before us already... we may regard this superfluous labour as a presumptuous sport which comes far short of nature" (Hegel, 1993). In other words, why would anyone recreate what is already there in reality, especially when what they create is incomparable to the real thing existing in nature? He asserts that these recreations only show "onesided depictions" and are not complete in form. Kant would readily agree with this perspective.

Another mode of thought Hegel considers is that art is used to teach, as Aristotle suggests, and more specifically to teach morals. This too for Hegel does not seem to make much sense since this suggestion calls into question why teaching requires art and why morals and other lessons cannot just be merely taught. Hegel argues that "if the purpose of art is limited to this didactic utility, then its other aspect, that of pleasure, entertainment, and delight, is pronounced to be in itself unessential" (Hegel, 1993).

Kosuth begins by asserting that art has a language, and that this language is the various forms of art, from which art takes shape. He writes, "If we continue our analogy of the forms art takes as being art's language one can realize then that a work of art is a kind of proposition presented within the context of art as a comment on art" (Osborne, 2002). This suggests the conclusion that art must be in some way attempting to extend the definition of what it means to be art. Art forming as the language of art is a concept which will provide for a way to understand what art is. Another notion which Kosuth asserts is that art should not and indeed does not have a truthness or a falseness to it. Going from this he states:

\footnotetext{
3 It is useful to note that Aristotle rejected Plato's theory of forms and so the resistance to false knowledge is not necessary.
} 
The unreality of realistic art is due to its framing as an art proposition in synthetic terms: one is always tempted to verify the proposition empirically. Realism's synthetic state does not bring one to a circular swing back into a dialogue with the larger framework of questions about the nature of art, but rather one is flung out of art's orbit into the infinite space of the human condition (Osborne, 2002).

Kosuth is referencing the tautology of the analytic terms of art's proposition. Here, he is suggesting that art, if taken for what it is, explains no fact and tells neither truth nor lie. What does this tell to us about art?

The overall argument presented here is that art is the artist's intention to show what can be considered to be art. Kosuth writes, "what is important in art is what one brings to it, not one's adaptation of what was previously existing," which is extremely important to our understanding this aspect of his aesthetic theory. He continues on, in the same fashion, to make a bold statement in reference to Pollack that "What is even less important to art is Pollack's notions of self-expression because those kinds of subjective meanings are useless to anyone other than those involved with him personally" (Osborne, 2002). Here we have two very important quotes directly addressing the question of what makes good art, or how does one incorporate this proposition appropriately into their art.

The first of these statements from Kosuth explains further that art not only needs to push the boundaries of the definition of art, but it must continuously bring forward a new thought to this definition. If one is merely continuing down the trend of new definitions and not bringing a new definition, Kosuth would not see this as good art. The second statement here explains to us that art does not need to be, and truly should not be, a sort of expression of the self which draws away from the art's context. Rather it seems, this new definition of art being created should remain within the context of art.

Walter Benjamin makes the claim that what art ends up doing, is not merely representing the current stage of society, but rather prepares and leads us towards a progression of society. Benjamin suggests this idea that art is not only to represent the current social situations and conditions, but to also prepare for and bring about new societal changes. One of the first statements he makes to suggest this is that

One of the foremost tasks of art has always been the creation of a demand which could be fully satisfied only later. The history of every art form shows critical epochs in which a certain art form aspires to effects, which could be fully obtained only with a changed technical standard, that is to say, in a new art form (Benjamin, 1935).

In other words, Benjamin is suggesting that, one of biggest concerns of art is to progress itself, since it sought to do something which could only be done with the advent of new ways of production. This is very similar to what Kosuth was suggesting in that both feel that art is attempting to extend its boundaries and progress art itself.

Benjamin continues on in his work to talk about what he calls distraction. What he means by this is that we, as a people, have become distracted from life. He uses film as an example of causing distraction, suggesting that film has a tendency to draw people into it, where they become not only an audience but also almost half-experience the film. In regards to this idea Benjamin suggests:

art will tackle the most difficult and most important ones where it is able to mobilize the masses. Today it does so in the film. Reception in a state of distraction, which is increasing noticeably in all fields of art and is symptomatic of profound changes in apperception, finds in the film its true means of exercise. The film with its shock effect meets this mode of reception halfway. The film makes the cult value recede into the background not only by putting the public in the position of the critic, but also by the fact that at the movies this position requires no attention. The public is an examiner, but an absent-minded one (Benjamin, 1935). 
Benjamin suggests, this notion of distraction, will make art cause societal shifts; mobilizing the masses in such a way that society changes and progresses. This is the first major point that Benjamin suggests in this passage. This social change Benjamin feels art brings about is started from this idea of distraction. As this passage points out, the audience of film (which brings this notion of distraction), is "absent-minded," they are drawn into the film and experience it rather than pay close attention to detail. But where does this lead society? Benjamin suggests that if aesthetics will be drawn into the political world it will have a terrible result. Humanity's "self-alienation has reached such a degree that it can experience its own destruction as an aesthetic pleasure of the first order," Benjamin writes (Benjamin, 1935). Art will depict catastrophes, yet because it is aesthetically pleasing, these catastrophes will become dulled out.

\section{The commonality of definitions}

Here we have discussed several ways in which art can be, and has been defined by major philosophers in aesthetic theory. So then, how do we best define art? Is there not something common to each of these methods and means of defining art? Indeed if there were, then we might use that as the grounding for understanding where the future of art might lead. Reconsidering the accounts outlined above, all of them refer to art as a form of representation in some manner, only organized differently. What I am suggesting will become more evident as we examine these theories defining art in terms of representation.

In both the accounts of Plato and Aristotle, art is mimesis, or imitation. There is obviously a connection with representation in such accounts, as imitation is representation itself. For Plato, art is representing what he calls "forms." In Aristotle, art is representing objects in nature, or reality. This is why in his understanding, art can be used to teach since there is nothing that is hidden in art, such as the forms would be in Plato's theory.

In Kant's theory as well, the impact of viewing art as a form of representation is also clear. For Kant there are two meanings of aesthetic: an original meaning and an extended meaning of the term. In his Critique of Pure Reason, the transcendental analytic refers to the pure forms of intuition from which we can sense the world around us, namely space and time. This, Peter Osborne suggests, is what Kant means by the "original use" of aesthetic, whereas aesthetic judgements of taste are the "extended use" (Osborne, 2013).

According to Kant, only the sensible element is purely aesthetic; the judgements of taste are flawed. Osborne writes that the error of these judgments for Kant, is due to a "failed hope" of "bringing the critical estimation of the beautifulunder principles of reason, and elevating its rules to a science"; that is, from the aspiration to a rationaldoctrine of the beautiful, an "aesthetic", in a scientific disciplinary sense"" (Osborne, 2013). Regardless, it is evident that both uses are forms of representation. The original use represents the sensible elements, whereas the extended meaning represents taste, or what is judged to be tasteful. Thus, we see how this line of thinking of art has continued even in Kant.

How does Hegel's theory of art form out of an understanding of art as representation? Very simply, Hegel asserts that art shows the current stage of Geist in history. What this means is that art shows us a current cultural status. This thought places the idea as the most important aspect of a work of art. However, since art is meant to show the spirit of the times, there is no good or bad forms or works of art, only those which represent the stage of Geist more accurately. Hegel explains this notion within its historical context by separating art into three forms: symbolic, classical, and romantic.

In the symbolic form of art, which was used during humanity's early history (pre-ancient Greeks), Hegel states that this was "a mere search after plastic portrayal [rather] than a capacity of genuine representation. The idea has not yet found the true form even within itself, and therefore continues to be merely the struggle and aspiration thereafter" (Hegel, 1993). So in this stage, art is created not to strictly represent something, but to symbolize something, a form of representation. An example of this 
style of art are the terracotta figurines by which the creator would attempt to symbolize something, such as fertility through making a very large breasted woman. Although the idea is being represented Hegel suggests that this representation is crude and that the idea is only abstractly represented.

After the stage of symbolic art, the idea becomes better represented, in the classical art stage. This phase of art, Hegel claims, "is the free and adequate embodiment of the idea in the shape that, according to its conception, is peculiarly appropriate to the idea itself. With it, therefore, the idea is capable of entering into free and complete accord" (Hegel, 1993). It is in this stage, Hegel is suggesting, that the complete form of the idea is in unity with the design of the art. The way classical art is most known for doing this is personification, or as Hegel calls it, the human form. This human form of art, puts the idea into art without leaving it completely abstract, or not as absolute and eternal, as Hegel says.

Finally, art reaches its third stage; that which Hegel refers to as the romantic stage of artistic representation. Art in this phase breaks down the unity that the classical phase had established. This stage of art is free from the boundaries of immediate existence, and transcends its own being, leading Hegel to claim, "in this third stage the object (of art) is free, concrete intellectual being, which has the function of revealing itself as spiritual existence for the inward world of spirit" (Hegel, 1993). Because this form of art finds itself as the inner world, it must also be a representation of the inner feelings. ${ }^{4}$

As one can see through Hegel's examples of the stages of art, each work of art within these phases is a way of representing what was important to a particular culture in a particular time, or as Hegel terms it, Geist. So, for the symbolic art phase, what was important were characteristics such as fertility, strength, courage, and other such traits that were seen as admirable or praiseworthy. This idea that art shows what people in that era deem to be important will prove to be important when thinking about where the future of art will lead.

Continuing on, how does Kosuth's theory relate to art as representation? Kosuth's theory on art is really based in thinking of art as a form of representation. More specifically, representation of what the definition of art is, and even more so the representation of the artist's intentions behind the work of art. As Kosuth had stated, art's proposition comes from the artist's intention. This shows that art is the representation of these artist's ideas of the definitions of what art is and of what can be considered to be art.

Kosuth has an additional claim to make about art as representation as well. He writes, "In this period of man, after philosophy and religion, art may possibly be one endeavor that fulfills what another age might have called man's spiritual needs... Art's only claim is for art. Art is the definition of art" (Osborne, 2002). Interesting here is the notion that art is representation of the spiritual needs of man. In other words, art is the representation of something which adheres to that in man which exists outside of the mundane world.

Both Kosuth's and Hegel's theories have something which they represent. They, together, show art as a way of progressing. For Hegel, art is about representing the current stage of Geist, or culture, whereas in Kosuth's theory we see that art is constantly attempting to expand its own boundaries. This suggests that as art continuously pushes its boundaries into new forms of representation, the current importance of the art is also changing. Therefore, we find that these two theories lead to a notion that art is a means of progression as well as a representation of that progression.

Just as with Kosuth and Hegel, Benjamin's theory on art also shows art as a form of representation. For Benjamin this is a representation of the current social conditions as well as starting society on a

\footnotetext{
4 Friedrich Shiller, "Kallias, or Concerning Beauty: Letters to Gottfried Körner" in Classic and Romantic German Aesthetics, ed. J.M Bernstein. Schiller has a theory of beauty which focuses on inner feelings which the art arises in the viewer. Particularly the beautiful is that in which we can recognize our own freedom.
} 
progression towards the future. But what is this future? Is this future really one of war and alienation? While Benjamin's theory on the future has its value, there are reasons to think, going back to Hegel and Kosuth as well, that the future of art will not be one such as Benjamin suggests, but rather the complete opposite.

\section{Art and representation}

In order to fully understand the future of art, of we must first think about what art is, something which each of the theorists discuss. With Kosuth suggesting art is always attempting to push its own definition, Hegel claiming art shows the current stage of history's progression, and Benjamin asserting that art reveals to us our current social conditions as well as prepares us for social change, it seems all but certain that art is rooted in representation of some sort. But what is art really representing? Is it the current stage of cultural importance, or the social conditions, or what art is, or does art instead represent art itself? What we mean by this last thought is not the same as Kosuth was suggesting. Art as representing art is a notion that Art forms, not forms of art, such as painting, photography, et cetera, are merely used to represent that which is art and as such, has nothing to do with the expansion of art.

Each of these theorists have defined art in a way in which it is used to represent something. However, each of them disagree as to what art is meant to represent. Not everyone would agree that art is aimed at representation, however. Gracyknotes, when discussing institutional definitions of art, that Duchamp's Fountain is art, regardless of anything that it does or is meant to represent (Gracyk, 2012). Instead, the piece gains status of art simply because it was placed in a particular environment. Most arguments against the suggestion that art is a means of representation follow this pattern. But this argument does not really hold up to scrutiny.

First, even if some art is only art insofar as it is in a particular environment, this is certainly not true of all art. If it were, then the unfinished painting is not art, as it is not yet in an art gallery or has not been made available for public viewing, etc. In short, only finished art, with an audience, can be called art, according to this objection. The fault in this argument is that it is not universal enough to contain all pieces of art.

Furthermore, would we truly be satisfied to understand that Duchamp had no reason behind such a piece? That is, would we feel just as appreciative of such a piece, should we know that there was nothing which it was meant to represent? Let us imagine such a scenario.

Imagine Duchamp shows you a desk with a paintbrush on it. Would you think it a piece of art? Probably not. Imagine next, go to an art gallery and see Duchamp's desk with a paintbrush on it as an exhibit. Is it art? Instantly one can assert that it is in fact a piece of art. Is this change due to the environment only? Or, is it instead due to the arousal of curiosity the piece arises within you over what it is meant to represent? Finally, imagine Duchamp shows you a new piece he is working on to represent the artistic process. When he reveals the piece, it is a desk with a paintbrush on it. Is it still art? Most likely you would say that it is.

Thus, it is not the environment that makes art what it is, but rather it is the fact that it is representational. This does not mean all art is representational art or that it is always clear what is being represented. Abstract, and nonrepresentational art can also be forms of representation, even if it is not straight-forward.

If then, we are to assert that all art shares in common, being a form of representation then it should be easy to establish exactly what art is representing. What then are we to decide art is representing? Is it representing reality or nature? Certainly this cannot be the only aim of representation as we said not all art is representational art. Perhaps it is best to first consider the meaning of art itself, in order to determine what art aims at representing, 


\section{The meaning of art}

Art itself, the Greek words techne ${ }^{5}$ andpoesis, ${ }^{6}$ actually refer not only to the fine arts but rather to a possession of a set of skills, the ability one has to create, and the creation itself. These crafts are distinguished by the various ends at which they aim and are associated with special kinds of knowledge. Therefore art is made up of much more broad categories, such as the art of movement or the art of speech. Here then, a distinction must be made. What we now consider art - painting, music, dancing etc. - are not arts in themselves, but are forms of art. Why is this so? as we have just eluded to, art itself is a much more broad category containing both these forms of art, or fine arts, as well as more general forms of art, such as chair-making, which we may term crafts. So then, what is art representing?

If we are to come to an understanding of what art itself is, we need to determine the category under which may be placed the two distinct forms of art, either fine arts or crafts. This is not to say that the two must be subdivided from the same art form, but only that the art forms must be categories such that both of these various forms of art may be both understood as subcategories of art in general. If we should take art to be categories such as these various forms of art, like painting, music, and so forth, then we exclude the crafts such as shoe-making, to use an Aristotlean-like example, as we have confirmed previously, for it is certain that shoe-making does not fit into any of these forms of art, nor of any conceivable form of art. Instead if we are to think of an art form such as 'knowledge,' then we would most certainly concede that shoe-making belongs as a form of the art of that category.

Thus, we may suggest that art is amalgamation of the general categories called art forms under which we may include both forms of art, fine arts and crafts. As such, falling in line with the advice of John Cage ${ }^{7}$, walking or talking in general are both representations of art forms: namely, the art of motion and the art of speech and language. One theorist who suggested a similar approach to understanding art, Clive Bell, wrote that "To appreciate a work of art we need bring with us nothing but a sense of form and colour and a knowledge of three-dimensional space" (Bell, 1961). Thus, the aesthetical element in a work is simply the color, shape, size, etc.

However, these art forms, as we termed them are as of yet not aesthetically pleasing. Thus, in order that there will be a factor which makes people appreciate such things more, there needs to be a more aesthetical way to represent these art forms through a form of art; in other words, so that these art forms can become fully appreciated, various forms of art, or the fine arts, are used in order to represent these art forms in a more aesthetical way. For that reason, the art of movement is now represented with forms of art such as dance, while the art of speech is represented by means of singing. These forms of art are simply more aesthetically pleasing in the current era. However, this is where the history of art leads and where the future of art rests.

\section{The future of art and concluding remarks}

As artists who utilize these various art forms continue to push the boundaries of how to best represent various forms of art, these representations will become, slowly, more like everyday occurrences, unlike the assertion of Guy Debord ${ }^{8}$, in terms of both the work of art and how the receptor of the art experiences it. For example, the before-mentioned exhibits of contemporary art that put on display

\footnotetext{
5 The Greek term for 'craft' or 'art' refers mostly to a 'craftsmanship' or an ability within a person to create.

${ }^{6}$ The Greek for 'to make' and is commonly used to mean 'art' as well. Specifically it refers to the actual creation of a thing, or the transformation of one thing becoming another.

7 John Cage, "26 Statements re. Duchamp" in Conceptual Art ed. Peter Osborne, 195. Cage writes that, "We must nowadays nevertheless at least be able to look through what's beyond - as though we were in it looking out." Thus, we are to get behind the beyond, to experience the world of art not just as viewer, but as a participant.

8 Guy Debord "Détournement as Negation and Prelude" in Situationalist International Anthology, ed. by Ken Knabb, 55-56. Debord suggests, "At this point in the world's development all forms of expression are losing grip on all reality and being reduced to self-parody."
} 
pharmaceuticals in medicine cabinets, thereby, taking from the distinction we have now established, representing the art of knowledge in a very similar way that shoe making is also of this kind.

As time progresses, more and more focus will be placed on the objects themselves such as in this display. IPods and other such devices will be considered art, perhaps they will be taken apart to show the complexity of the design, still representing the art of knowledge, only expanding how the art form is used. Film will give way to a more "hands-on" experience, perhaps something along the lines of virtual reality ${ }^{9}$, as technology develops.

Over time, this development will then lead to a stronger focus on the experiences of everyday life: walking, talking, colors, shapes, and sounds. As these are more directly related to, or are in themselves Art forms and will become more evidently aesthetical in and of themselves, no longer requiring indirect representation from various forms of art in order to be appreciated as Art, as the form of art will have its own aesthetical value. Exempli gratia, one will no longer need music to find the aesthetical value in the art of sound as the leaves blowing in the wind will thus become its own music. ${ }^{10}$

This is not to suggest music will become obsolete. On the contrary, music will remain crucial to life, but that which is considered music will change into the art form itself, rather than being represented through a form of art such as a fine art or a craft. The end of this transformation process leads to a greater appreciation of life, since one is recognizing the aesthetical value, or beauty, of life itself; id est this act of regarding the sound of leaves, or other everyday noises, as music, and so on, will also lead to an overall change in attitude towards life, a more, aesthetical way of life.

Taking these notions of the future of art and by looking at what constitutes art, it was concluded that art is much broader than mere fine arts or crafts. Then, through examining this distinction it was concluded that the future of art will place an emphasis on the art forms themselves, rather than the art forms requiring representation through forms of art in order that they become aesthetically pleasurable; that is to say we suggested an aesthetical shift.

This shift in aesthetical value will eventually lead to the understanding of life as being aesthetical in and of itself, without the need for aesthetic fillers, and thereby eliminating controlled cultural consumption which Benjamin H.D. Buchloh suggests art concerns itself with during the late sixties. ${ }^{11}$ Through this analysis of art and its future, it was evident that the future of art can put forth, not the viewing of aesthetical desolation, but rather a greater appreciation for the beauty that is life.

This proposition leaves open many future possibilities, however it suggests a future of art in which art is no longer viewed as art, but rather that entities in the world can be considered aesthetical. To put it simply, this brings to the forefront the discussion of the distinction between art and the aesthetic, with an emphasis on the latter as a means of facilitating different, and improved possibilities of human futures. Moving forward, research devoted to these new human futures ought to include the insight that the aesthetic of everyday life offers.

\footnotetext{
9 The idea here is that movie-goers may 'experience' the movie in a more direct way than current means offer. For example, the viewer being placed into a character in the film and enjoying the film from a character's specific point of view.

${ }^{10}$ Herbert Marcuse, AnEssay on Liberation, 27. Marcuse writes, "the aesthetic dimension can serve as a sort of gauge for a free society. A universe of human relationships no longer mediated by the market, no longer based on competitive exploitation or terror, demands a sensitivity freed from the rep ressive satisfactions of the unfree societies; a sensitivity receptive to forms and modes of reality which thus far have been projected only by the aesthetic imagination," a similar perspective to the one proposed.

${ }^{11}$ Refer to Benjamin H.D. Buchloh's Conceptual Art 1962-69: From the Aesthetics of Administration to the Critique of Institutions, "These institutions, which determine the conditions of cultural consumption, are the very ones in which artistic production is transformed into a tool of ideological control and cultural legitimation” (p. 143).
} 


\section{References}

Aristotle \& Heath, M. (1996). Poetics. London: Penguin Books.

Bell, C. (1961). Art. Arrow Books.

Benjamin, W. (1935). The work of art in the age of mechanical reproduction. Retrieved April 16, 2017, from http://ada.evergreen.edu/ arunc/texts/frankfurt/benjamin/benjamin.pdf.

Bernstein, J. M. (2006). Classic and romantic German aesthetics. Cambridge: Cambridge University Press.

Buchloh, B. H. (1990). Conceptual Art 1962-1969: From the Aesthetic of Administration to the Critique of Institutions. October, 55, 105-143. doi:10.2307/778941

Carrier, D. (2011). The Future of Art History in the Context of Psychology and the Cognitive Sciences. Leonardo,44(5), 386-386. doi:10.1162/leon_e_00236

Clowney, D. (2011). Definitions of Art and Fine Arts Historical Origins. The Journal of Aesthetics and Art Criticism,69(3), 309-320. doi:10.1111/j.1540-6245.2011.01474.x

Crowther, P. (2011). Defining art, creating the canon artistic value in an era of doubt. Oxford: Clarendon Press.

Currie, G. (2010). Actual Art, Possible Art, and Art's Definition. The Journal of Aesthetics and Art Criticism,68(3), 235-241. Retrieved from http://www.jstor.org/stable/40793265

Dickie, G. (1974). Art and the aesthetic: an institutional analysis. Ithaca, NY: Cornell Univ. Press.

Fenner, D. E. (1994). Why Define 'Art'?. The Journal of Aesthetic Education,28(1), 71-76. doi:10.2307/3333160

Gracyk, T. (2012). The philosophy of art: an introduction. Cambridge: Polity.

Hegel, G. W., Bosanquet, B., \& Inwood, M. (1993). Introductory lectures on aesthetics. London: Penguin Books.

Jagodzinski, J. (2005). Virtual Reality's Differential Perception: On the Significance of Deleuze (and Lacan) For the Future of Visual Art Education in a Machinic Age. Visual Arts Research,31(1), 129-144. Retrieved from http://www.jstor.org/stable/20715374

Kant, I., \& Pluhar, W. S. (2010). Critique of judgment. Indianapolis, Ind: Hackett.

Knabb, K. (2007). Situationist international anthology. Berkeley: Bureau of Public Secrets.

Lopes, D. M. (2008). Nobody Needs a Theory of Art. Journal of Philosophy,105(3), 109-127. doi:10.5840/jphil200810531

Marcuse, Herbert. (1969).An essay on liberation. London: Allen Lane/Penguin Press.

Osborne, P. (2002).Conceptual art. London: Phaidon,.

Osborne, P. (2013). Anywhere or not at all: philosophy of contemporary art. London: Verso Books.

Plato, \& Bloom, A. (1968). The republic of plato. New York: Basic Books.

Piene, O., \& Russett, R. (1986). Sky, Scale and Technology in Art. Leonardo,41(5), 511-518. doi:10.2307/1578236

Seabolt, B. O. (2001). Defining Art Appreciation. Art Education,54(4), 44-49. doi:10.2307/3193903

Wilson, S. (2008). Destinations of Feminist Art: Past, Present, and Future. WSQ: Womens Studies Quarterly,36(1-2), 324-330. doi:10.1353/wsq.0.0056 